\title{
A Smart-Merging Facilitation Model (SMFM) of meaningful learning for life and work in the digital era
}

\author{
Irina Maslo•
}

\begin{abstract}
In the context of the smart specialization of national economies and the creation of smart societies in the digital age, general, vocational, adult, and higher education reforms have a decisive horizontal effect on the transition to smart education. A smart pedagogical approach that has evolved in recent years is frequently seen as merely focused on using new technologies in changing learning environments, nor on implementing the new smart educational philosophy on smart human learning for smart economies and societies of the digital era. Principally, new pedagogical approaches that "will undergo drastic changes and create new pathways for learners of all ages" (Scott, 2015, p. 16) are necessary. To supply this demand, pedagogy has to address meaningful learning, bringing it to life and work. Therefore, the question is "What does smart pedagogy imply in the digital age?" An exploratory research design of this paper simply ascertains the research question, leaving room for further research. To discuss this question, the concept of smart pedagogy has been argued in this paper. The evidence on the efficiency of smart learning facilitation has been explored through the learning analytics and students' self-evaluation statements in the framework of the 20152020 case study of the master's degree programme "Educational Treatment of Diversity" of the University of Latvia, as one of the best practice cases on preparing teachers for diversity in initial teacher education. (European Commission, 2017). The theoretically-founded and empirically-based authored smart learning facilitation model has been discussed and conclusions drafted for an international audience.
\end{abstract}

Keywords: smart pedagogy; meaningful learning; facilitation model; learning analytics; objective hermeneutic analysis

\section{Introduction}

The demand for the smartness of education is not a new challenge, but it has become more needed than ever in the unpredictable, changing labour and life situations in all regions of the world. Employer surveys show that the professional competence of employees is no longer sufficient to meet the needs of labour (OECD, 2013; OECD, 2017). In addition to specialized knowledge, professional skills and competencies, employees need to demonstrate today their capability to ensure the smartness of life and work in changing contexts. A prerequisite for the successful introduction of smart education is the

\footnotetext{
- Dr. habil. paed., Professor, University of Latvia, Faculty of Education, Pedagogy and Art, Department of Education Sciences and Pedagogical Innovation, irina.maslo@lu.lv
} 
continued professional training of teachers and opportunities for professional development in a conceptually new quality. This raises conceptually other requirements for the training of young teachers, as well as the professional development of current teachers, requires educators to "look outside schools and seek ideas, resources, and expertise where they are found - in their communities; in professional and educational groups; and in individuals, schools, and organizations around the world" (P21, 2007, p. 1; Scott, 2015, p. 12).

The smart pedagogical approach that has evolved in recent years argues for the opportunity of using new technologies to "enable learners to learn more effectively, efficiently, flexibly, and comfortably in a classroom environment" (Zhu et al., 2016, p. 1) in a digital age. Following Gil-Garcia (2016), it is to state that there are shortcomings in such an approach. On the one hand, the comprehension of smartness seems often reduced to an ICT-supported classroom environment managed by using traditional school or higherschool science subject content. On the other hand, the teachers are orientated only to eenvironment classroom management. However, they are not being prepared to implement the new smart educational philosophy on smart human learning for smart economies and societies (Uskov et al., 2015, 2016, 2018; Jeladze et al., 2018). The contribution of ICTs (Lytras et al., 2018) allows only more learner-centred approaches, making personalised learning possible. The principally new pedagogical approaches, which "will undergo drastic changes and create new pathways for learners of all ages and abilities", are demanded (Scott, 2015, p. 16).

The concept of smart pedagogy presented in this paper was developed in 2007-2017 at the University of Latvia through longitudinal research on complex innovations implemented in the Master's degree programme on Educational Treatment of Diversity in Latvia. Alongside being an academic, this programme has been an informal continuing workplace training programme for university teacher-staff. It has been the first programme in Latvia where the complex of innovations for facilitating informal learning has been implemented in a systematic way. These innovations have been implemented with a high impact on the restructuring of higher e-education in Latvia. The programme was selected as one of the 15 European best practice cases on opening higher education for adults in 2013 (European Commission, 2013) and on preparing teachers for diversity in initial teacher education in 2017 (European Commission, 2017, School Education Gateway, 2017).

In this paper, the smart educational philosophy and smart pedagogy have been argued in relation to the research question of what smart pedagogy implies in the digital age. The theoretical framework of smart pedagogy has been synthesized and the smart learning facilitation model constructed based on evidence practice. The evidence-practice of smart learning facilitation features has been provided through learning analytics and qualitative analysis of students' self-evaluation statements explored in the longitudinal case study. 


\section{Theoretical background}

The hundred-year long history of the development of pedagogy shows that pedagogy was always human-centred. Whether a human is viewed as an individual (pedagogy as humanitarian sciences or humanities, education science, and art) or as a social being (pedagogy as social science) is dependent on societal human values and ideals, as well as natural science understanding of human nature. The meaning of 'human development' through education differs in both cases. Without going into further details, pedagogy as the art of education of humans is human individual capability-centred, rather than it is mass education of individual nature (Freire, 2007). Pedagogy as social science stresses the social nature of a human being, 'hominis prosocialis' (Buchkremer, 1995, p. 316-317). A new challenge in the development of pedagogy as social science to the threshold of the 21st century is going "through four complicated transformations: knowledge hierarchy, social activities, community organization and modern system science, which demonstrates the breadth and depth of its changes" (Su Yong, 2014, p. 525). Pedagogy, as an inter-and trans-disciplinary system-science, aims to develop smart human capabilities in smart societies (smart technologies, smart cities, smart communities, and so on).

Already in the old "Vedas", we can find artefacts on smartness as the quality of a human being smart-minded or capable of learning informal smart. As well, digital-era entrepreneurs share their experience and mark smart thinking as their key to success (Robinson, 2009; Bet-David, 2016). The mind receives information from the senses, reaches for things important for a human by analysing the environment and the world of our experience. The smart mind defines what is needed for human beings in the context of the ideas to achieve these smart goals. The smart-minded human (Karlsone, 2018) by choosing action pathways meets smart reasons. As Boffo (2017) states, "the ability to gain awareness of observed behaviours and reflect on them is essential for role modelling to be effective" (p. 159).

The original theoretical framework on smart learning facilitation was inspired by the need for additional research on the causality of various conditional variables in workplace training (Brown, 2017; Ehlert, 2020). It sets up the social-ecological approach, where every person contributing or influenced is part of a social-ecological system through a set of interdependencies (Evans, 2019). It aims to develop an understanding of the complexity of conditions that impact directly or indirectly on human smart thinking facilitation, bringing meaningful learning to life and work situations.

Inspired from Scott's (2015), Uskov's et al. $(2015,2016 ; 2018)$ and Jeladze' et al. (2018) inputs to create new pathways for learners of all ages founded in smart educational philosophy on smart human learning for smart economies and societies, we believe that the smart-merging subject content, using the ICT and pedagogy facilitation model will contribute to the development of a holistic learning system oriented on transformational smartness of themselves as a collaborative person for strengthening the collective capacity (Sava et al., 2020) of workplaces and communities as qualitative life- 
and work-places. The "smart learning facilitation constructs" and the "smart learning facilitation principles" bringing meaningful learning to the life and work will be explored in this paper.

\section{Methodology \\ Research design}

To construct a holistic smart learning facilitation model oriented on the transformational smartness of themselves as collaborative people for strengthening the collective capacity of workplaces and communities as qualitative life-and workplaces, the "smart learning facilitation constructs" bringing meaningful learning to life and work have been explored.

The exploratory-research (Creswell, 2012; 2014) has been conducted to study a problem that has not been clearly defined yet to an understanding of the problem willing to change the direction of learning facilitation resulting from the revelation of new data and new insights (Saunders et al., 2012). Therefore, exploratory research design simply explores the research question, leaving room for further research, whereas conclusive research design is aimed at providing final findings from the research. Moreover, it has been stated that "an exploratory study may not have rigorous methodology as it is used in the conclusive studies, and sample sizes may be smaller. But it helps to do the exploratory study as methodically as possible, so as it is going to be used for major decisions about the way we are going to conduct next studies (Nargundkar, 2003, p. 41).

\section{Methods}

\section{Participants and context}

Four student-groups (2015/2016; 2016/2017; 2017/2018; 2018/2019) of one of the best master's degree studies programmes at the University of Latvia for preparing teachers for educational treatment of diversity (Public Policy and Management Institute, 2017) were involved in the explorative research. In total, 53 students from different countries studied in this programme in the research period: approximately fifty-fifty "from home and host" (Japan, Spain, Germany, Austria, Turkmenistan, Croatia, Italy, Mexico, Japan, the Check Republic and others).

The workforce master programme is designed to improve students' basic, generic, transversal, and professional competences which are necessary for them to work in various enterprises according to the changing workplace needs for teamwork; selforganization of work; readiness to participate, communicate, and to work' responsible; to analyse and decide; to assume the workload, and to succeed. It reveals that they have been trained as specialized professionals to work in education for people with diverse special needs, and that they have been prepared to research in different fields related to education with people with diverse needs related to students' workplace. By using such competences, the students create knowledge to generate smart solutions in diverse 
projects or situations. Essentially, content used to promote competences helps students to be appropriately prepared:

- To know 'what' to learn and 'how' to learn it: what needs to be learned and why it needs to be learned;

- To know 'how' and 'what for' to do anything to be capable to choose what must be done in order to be successful in one's endeavours;

- To know 'how' to be means taking on one's own duties and responsibilities.

The modular system of the programme is construed according to the principles of smart pedagogy, ensuring the advancement of students' competence development. Each module has five units designed in an interactive, self-organized e-learning mode, combined with face-to-face meetings (Birzina et al., 2009).

The e-contents and e-learning activities (each module has 5 smart merging activities related to number of units), formative and summative assessment are constructivist aligned, in order to promote students' smart-merging course subject content, ICT usage and pedagogy learning, and to offer a balanced allocation of time (3 weeks for each module).

Learners' autonomy and self-responsibility for outcomes (self-evaluation of demonstrated competences using rubrics) of collaborative activities are respected and supported. The particular needs of adult learners are taken into account: the learners can choose the time, intensity, place, and pace by using information and communication technologies and at least two European languages (Luka et al., 2009), and English as the language of instruction in the author's implemented courses in the research period 20152018 due to their teaching to foreign students together with Latvian students.

\section{Data selection}

\section{Observation}

Students' active (meaningful) participation in course activities has been participatory observed (Martinez et al., 2016). The author of the article was involved as a teacher in the master's program in the period 2015-2018 and, from this position, noticed that the activity of students in some program courses is much higher than in others.

\section{Temporal learning analytics}

The findings of the participatory observation were validated by using temporal learning analytics (Chen et al., 2018, p. 7) to identify the most active participated courses and their potential for further qualitative analysis. Figures No. 1-2 and Table No. 1.

\section{Self-evaluation rubrics}

The 105 self-evaluation rubrics of two selected courses, presented in the results section of the current paper, were chosen from the Moodle database for qualitative analysis of the 
textual meanings of "meaningful learning" and implicit "smart-merging constructs" that facilitate meaningful learning, bringing it into life and work, and sufficient conditions that appear in some cases as constant factors or principles of smart pedagogy for meaningful learning facilitation for life and work in the digital age in students as research subjects statements. Three students (one Latvian, one ERASMUS+, and one permanent foreign student) from the students' self-evaluation database were chosen for a trial "open and content coding" to ensure that the textual meanings in the students' self-evaluation rubrics are independent of their country of origin.

\section{Data analysis}

An objective hermeneutic analysis approach (Wernet, 2009) in favour of the master students of the University of Latvia judgments as the creators of real educational practice and research subjects was chosen. The researcher's task was to create a category system using "open coding" (Saldaña, 2016), which reveals the conceptual framework of the students' "meaningful learning through smart facilitation", bringing it to life and work.

Two hermeneutic analysis strategies were used for this purpose: empathy and assumption formulation.

The first strategy revealed word analysis of the self-evaluation statements, which was used in the first cycle of the analysis to understand the student's judgment as close as possible to the text ("open coding" of students' statements about meaningful learning for life and work). Table No. 2.

The second strategy revealed what was meant by the "open coding" judgment in the second cycle of analysis (content codes to identify the "smart learning facilitation constructs". Table No. 3.

To answer the research question of this paper "What does smart pedagogy imply in the digital age?" the interaction structures between open and content codes in the selfevaluation texts were determined for minimisation the data (Benoît \& Ragin, 2009).

The properties of sufficient and necessary conditions in a data frame (Huber \& Gürtler, 2012) were inspected to define the most notably, minimally sufficient and necessary principles that appear in cases and should be considered as constant factors (Benoît \& Ragin, 2008, p. 63-68; Baumgartner \& Thiem, 2015, p. 6). Table No. 4. 


\section{Results}

\section{Students' meaningful leaning, bringing it to live and work}

The participatory observation findings over time, 2015-2018, serving the professorship position in several programme courses, suggested that students' active participation in course collaborative activities displays their meaningful learning, bringing it to life and work. Such an assumption was viable because the author's themselves-directed courses, unlike other courses in the program, were implemented in a way that would strengthen students' collective capacity (Sava et al., 2020) and thus students' smart thinking capability. To prove this supposition, the findings of the participatory observation were validated by using temporal learning analytic to identify the most active participated courses and their potential for further qualitative analysis. The available Moodle learning analytics data from 2015-2018 confirmed this assumption. Figure No. 1-2.

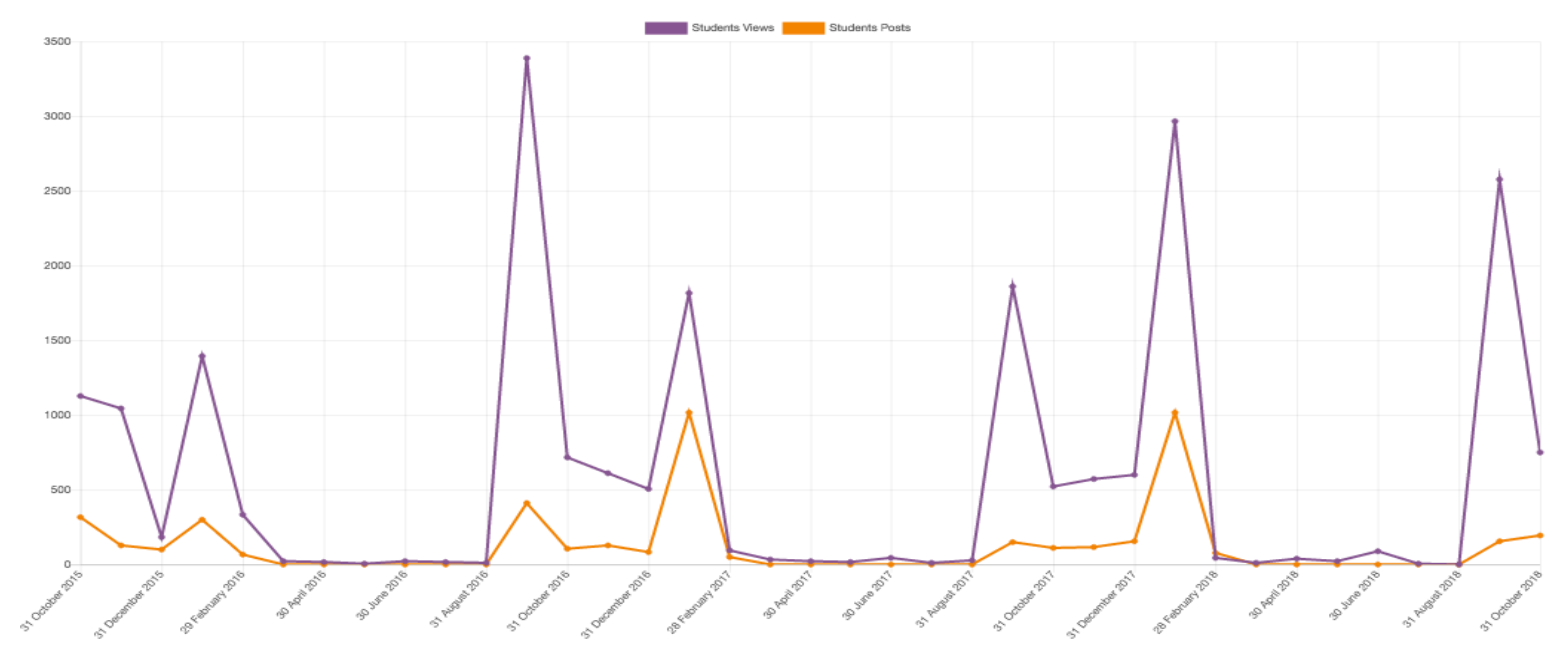

Figure 1. Evidence on students' active learning in programme courses modules (data October 2015-December 2016)

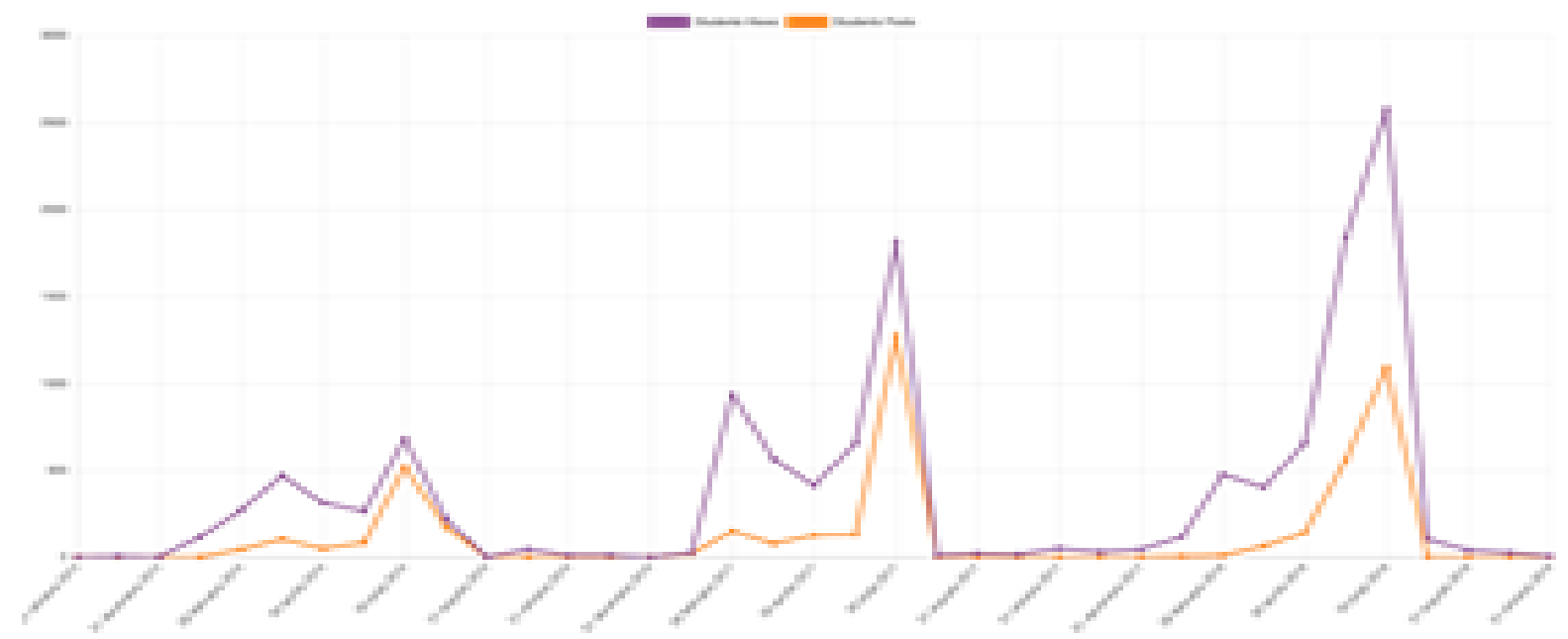

Figure-2. Evidence on students' active learning in programme courses modules (data February 2017-October 2018) 
Two modules quantitative data demonstrated the highest involvement of students themselves in the mastering of activities throughout all tested learning analytics data in a research period (Table 1-2). These were both designed in a collaborative learning modality, unlike the others. For ethical reasons, they have been named modules $\mathrm{X}$ and $\mathrm{Y}$. Table No. 1.

Table 1

Evidence on students' active learning in modules X and to (data 2015-2018)

\begin{tabular}{llll}
\hline $\begin{array}{l}\text { Period ending } \\
\text { (Month) }\end{array}$ & $\begin{array}{l}\text { Usage of } \\
\text { resources }\end{array}$ & Posts & Comments \\
\hline $31 / 10 / 18$ & 752 & 191 & \\
$30 / 09 / 18$ & 2575 & 156 & Module X \\
$31 / 05 / 18$ & 21 & 0 & \\
$30 / 04 / 18$ & 39 & 0 & \\
$31 / 03 / 18$ & 8 & 0 & \\
$28 / 02 / 17$ & 937 & 148 & Module Y \\
$31 / 12 / 17$ & 601 & 113 & \\
$30 / 11 / 17$ & 572 & 109 & \\
$31 / 10 / 17$ & 522 & 148 & Module X \\
$30 / 09 / 17$ & 1859 & 0 & \\
$30 / 06 / 17$ & 41 & 560 & Module Y \\
$31 / 05 / 18$ & 1837 & 0 & \\
$30 / 04 / 17$ & 24 & 0 & \\
$31 / 03 / 17$ & 31 & 48 & \\
$28 / 02 / 17$ & 91 & 85 & \\
$31 / 12 / 16$ & 505 & 126 & \\
$30 / 11 / 16$ & 610 & 102 & \\
$31 / 10 / 16$ & 716 & 409 & Module X \\
$30 / 09 / 16$ & 3391 & 0 & \\
$31 / 05 / 16$ & 3 & 0 & \\
$30 / 04 / 16$ & 13 & 0 & \\
$31 / 03 / 16$ & 19 & 64 & \\
$29 / 02 / 16$ & 333 & 98 & Module Y \\
$31 / 12 / 15$ & 183 & 127 & Module X \\
$30 / 11 / 15$ & 1044 & 317 & \\
$31 / 10 / 15$ & 1127 & &
\end{tabular}

Note. Columns 1-3 contain data from the programme's Moodle learning analytical statistics.

The students' statements of 105 self-evaluation rubrics from the selected courses were qualitatively analysed to ensure that active learning is also meaningful learning, bringing it to life and work. The "textual meanings" word analysis of the 105 selfevaluation statements showed that active learning is an open-minded, intensive, and deep learning approach that lets the students become self-confident and share experiences among their family members, friends, and colleagues, and so that transforms their 
learning into meaningful learning for life and work, independently of their country of origin. Table No. 2.

Table 2

The Matrix of the "textual meaning" of active and meaningful learning for life and work

\begin{tabular}{|c|c|c|}
\hline Active learning & Meaningful learning & Example quote \\
\hline Open-minded & $\begin{array}{l}\text { For daily life } \\
\text { as well as for } \\
\text { work }\end{array}$ & $\begin{array}{l}\text { Student No. 17: "I mainly learned in this } \\
\text { course to be open-minded as much as } \\
\text { possible during daily life as well as at } \\
\text { work because that can only enrich my } \\
\text { knowledge." }\end{array}$ \\
\hline Intense and deep & $\begin{array}{l}\text { Becoming self- } \\
\text { confident } \\
\text { Sharing experiences }\end{array}$ & $\begin{array}{l}\text { Student 3: "I have become self-confident } \\
\text { in this subject. I have got a lot of plans } \\
\text { for my future development... I have } \\
\text { shared and placed received knowledge } \\
\text { among my family, colleagues, and } \\
\text { friends as well." }\end{array}$ \\
\hline
\end{tabular}

Note. Word codes analysis of the 105 self-evaluation rubrics' statements was made in the first cycle of the explorative research to understand the student's judgment as close as possible to the text by "open coding" of students' statements about active and meaningful learning for life and work. The data was collected in English and wasn't edited to preserve the authenticity of the quotes.

\section{Implicit constructs for facilitating meaningful learning}

The analysis of content codes allowed us to explore what is meant by "open coded judgments" and thus identify "smart-merging constructs" that facilitate meaningful learning, bringing it into life and work. Table No. 3.

Table 3

The Matrix of implicit constructs for modelling smart learning facilitation

Implicit constructs $\quad$ Example quote

Merging subject-content, ICT

usage and pedagogy ${ }^{\mathrm{a}}$

Smart-merging subjectcontent studies in a pedagogically organised e-learning collaborative

Student 11: "We have actively used e-mail, Skype, face to face discussions, mobile phones. free of charge, available materials and possibilities to use universities' web access to scientific environment using e-tools databases, use libraries, use educational and ICT technologies. materials, I-net, books, collaboration, previous knowledge and practice, scientific web-based portals, participate at web-conference."

Smart-merging subjectStudent 35: "Our group worked via WhatsApp. content studies in a The analysis was made collaboratively in google 


\begin{tabular}{cl}
\hline Implicit constructs & Example quote \\
\hline pedagogically organised & docs. We are diverse professionals in our group \\
interactive e-learning & and trying to be assistance for any other. The \\
communication & participation in the group discussions was \\
communities using e- & interesting, but everybody still has their own \\
tools and ICT & opinion on multicultural diversity and teaching \\
technologies & $\begin{array}{l}\text { processes in the context of multicultural } \\
\text { diversity. The structured critics from my group } \\
\text { mates gave me so many useful goals for the future } \\
\text { and many ideas for my practice improvement. I } \\
\text { enjoyed this activity really." }\end{array}$
\end{tabular}

Merging basic, general, transversal and professional learning outcomes ${ }^{b}$

Smart-merging basic, general, transversal and professional learning outcomes in multidimensional social ecological contexts

Student 44: "This module was very useful and reinstructive - I reminded many important subjects as well as gained new pedagogical approaches and methods and the WHYs and HOWs of them (unit 4). I developed in my teaching and reflection this school year and highlighted my successes and places for growth, as well as cemented my certainty of self-regulated skills' importance in guaranteeing the differentiated approach in a school system, that is necessary for every classroom to satisfy all the diverse needs. And had a lot of deep personal contemplations around social-cultural contexts and myself. I have not had since my theology studies."

Smart-merging self-

Student 27: "Through the stages of higher evaluation of demonstrated basic, general, transversal and professional competences in multidimensional social ecological contexts education that I have experienced, I have been approaching and slowly starting to embrace the concept of meaningful, focused and self-directed studies. All of the empiric experience that has been previously gained builds and helps develop the overall self-evaluation and cognitive dimension. Exactly these studies are, through which I have reached the most controversial conclusions."

\footnotetext{
a Analysis of the content codes in the 105 self-evaluation rubrics' statements was made in the second cycle of the explorative research to identify "smart-merging constructs" that facilitate meaningful learning, bringing it into life and work. The data was collected in English and wasn't edited to preserve the authenticity of the quotes.

b The implicit (or enfolded in students' statements) constructs for modelling smart learning facilitation in the digital age) integrate two main interconnected sub-constructs: 1) a smart-merged subject matter content with ICT usage, collaboration, and communication pedagogy; and 2) a smart-merged personalized combination of fundamental, general, transversal, and professional learning outcomes, as well as selfevaluation of demonstrated competences in multidimensional sociocultural contexts.
} 


\section{Smart-merging learning facilitation conditions}

The interaction structures between open and content codes in the self-evaluation texts were determined for minimisation of the data and to inspect the properties of sufficient and necessary conditions in a data frame. The most notably, minimally sufficient conditions that appear in cases have been considered as constant factors or principles of smart pedagogy for meaningful learning facilitation for life and work in the digital age. Table No. 4.

Table 4

The Matrix of smart pedagogy implementation principles for facilitating meaningful learning for life and work in the digital age.

\begin{tabular}{ll}
\hline Interaction structures & Example quote \\
between & \\
word and content codes a & \\
\hline
\end{tabular}

Flexibility

Constructivist alignment

Student 23: "This course showed me that it is useful to be flexible in general, not only concerning different media, etc. Moreover, I learned how to deal with different techniques. It makes a course more interesting when you try learning with different media, for example, Skype, web conference, or Google drive. In addition, it is easy for students as parents who are working, because they can study at home and do not have to go to university. Being flexible is very important."

Student 53: "This was a rather philosophical module, with humanism's features, and through thinking about what it means to be human (for example, a new perspective - responsibility to learn, adapt, and preserve) in a social context, what it inseparably means to take in integration as a part of one's world view. And I believe that by being truthfully inclusive I am promoting integration, because in my actions I promote it, not only knowingly but without intention, since my mind set has changed, and I like to think it has improved."

Multidimensionality of Student 51: "I have a lot of plans and changes for the ecological contexts next school year (Activities of the Unit1) considering my students' not only as individuals, but as well as part of society and helping them to see their place in it, and trying to keep in balance my duties and their interests. Seeing my workplace, the school where I teach, as a living organism, where each person is vital for its growth (Activities of Unit 2) and responsible for its inclusion in society and as well as its growth." 


\begin{tabular}{ll}
\hline Interaction structures & Example quote \\
between & \\
word and content codes a & \\
\hline
\end{tabular}

Smart pedagogical leadership
Student 7: "For future work, I want to act effectively so that the social-cultural learning situation can become more humane. My work area or my school's educational area has empathy for other people's social-cultural learning situations. We need to realize what a powerful thing it is to have diversity all-around us. We can use it to our advantage in our academic lives. So, the ultimate aim of human-act should be the development of compassion, with empathy as an important step in this process."

a The four constant factors or principles of smart pedagogy for meaningful learning facilitation, bringing it into life and work in the digital age, were determined through minimisation of the data in a data frame in the third cycle of the explorative research. The data was collected in English and wasn't edited to preserve the authenticity of the quotes.

\section{Discussion}

The theoretically founded (Saunders et al., 2012; Scott, 2015; Uskov et al., 2015; Uskov et al., 2016; Uskov et al., 2018; Boffo, 2017; Jeladze et al., 2018; Brown, 2017; Evans, 2019; Ehlert, 2020; Sava et al., 2000) results of the hermeneutical analysis of the empirical data of evidence-practice discovered the smart merging facilitation features. The clearlytraceable demonstrated "smart-merging-learning-constructs" and "smart-merginglearning facilitation principles" bring meaningful learning to life and work.

Smart merging learning is focused, on the value of the human smartness as an added value for themselves in life- and work, for their families and workplaces, for smart economies, smart societies and smart humanity.

The Smart Merging Learning Facilitation Model (SMFM) integrates science (subject contents), pedagogy and ICT. It is focused on the transformational smartness of themselves as collaborative humans to strengthen the collective capacity of workplaces and communities as qualitative life-and work-places.

The SMFM implies existing and new digital educational technologies to meet the demand for flexibility (Principle 1) for personalisation of smart-merging learning. It aligns the intended smart-merging learning outcomes, smart-merging learning ecommunities, and smart-merging collaborative learning activities (Principle 2) into the universal constructivist pedagogical leadership system (Principle 3), specifying them for different multidimensional social-ecological contexts (Principle 4). Figure No.3. 


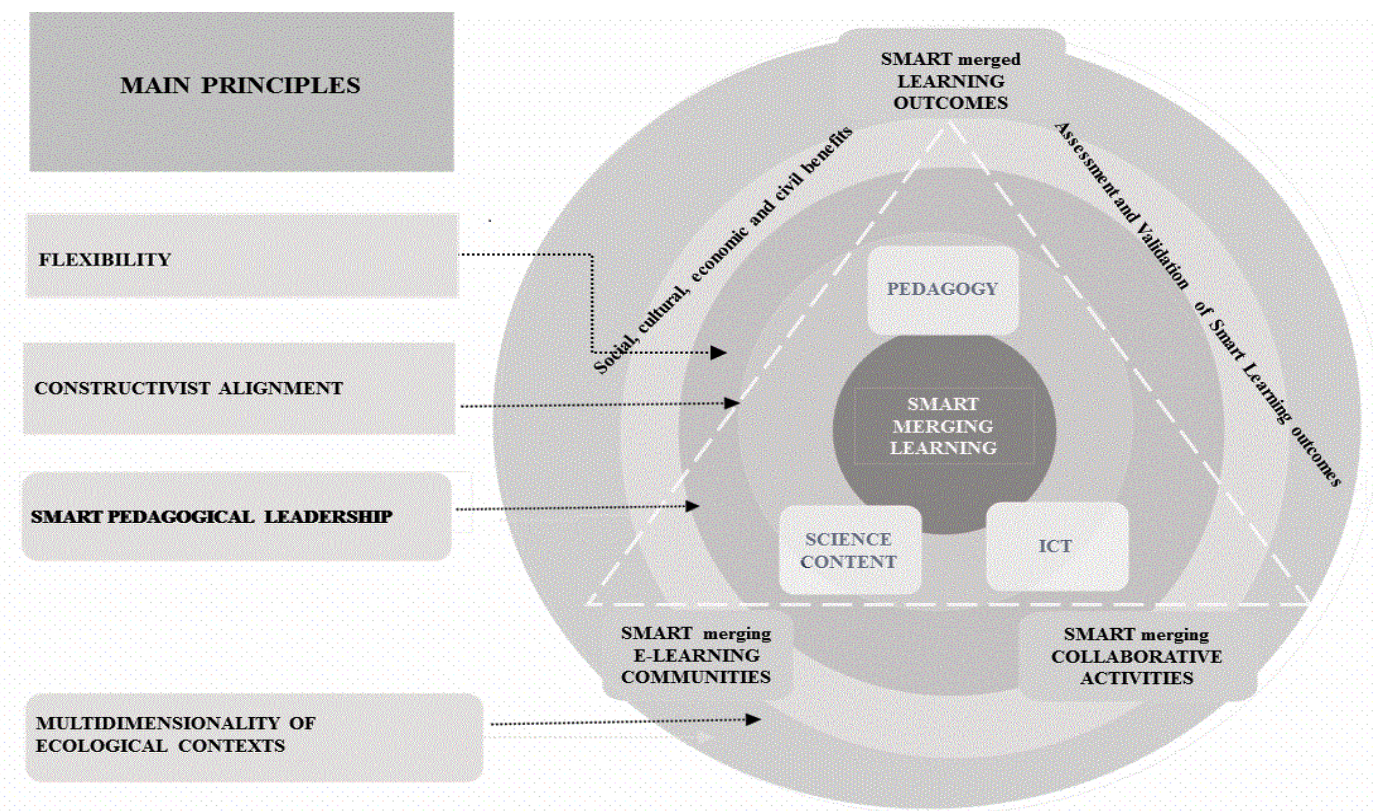

Figure 3. A theoretical framework of smart-merging facilitation model

\section{Conclusions}

Meaningful learning is open-minded, social-ecologically transformational, active, intense, deep, constructive, and smart-merging learning. It goes beyond simple learning in the eenvironment in the digital age. It causes fundamental changes in our world views in the transition from the uncontested acceptance of available information to its critical reflection, causing profound changes in our souls, feelings, life and work perspectives, beliefs and behaviour. Smart digital educational technologies provide new opportunities only for identifying and promoting such changes.

Students' focus on their smart-merged investment in the quality of mastering collaborative tasks versus own performance is a challenge to be transformed into a new opportunity to shift the mind from the desire to be the best student to the desire to actively participate in mastering open activities throughout constructivist mutual smart learning. So then, the learning content/materials, practical collaborative activities and assessment have to provoke the learners to shift from the individual learning to the learning of something which is not agreed but anyone has any desire to know.

Mutual learning in small, self-organized e-learning groups assists in mastering learning activities in a meaningful way for life and work by explaining to one another the smart-merged learning contents acquired in real life and work situations, being peer and team smart learners.

Building the smart e-learning community strengthens the collective capacity by using smart digital educational technologies as new opportunities for identifying and promoting smart minding significance for smart learning benefits for the social-ecological system.

Smart pedagogical leadership as a multidimensional process and a sustainable facilitation system of consideration of the smart-merging learning outcomes, 
opportunities for collaboration and communication that appear in social, cultural, economic, and civic ecological contexts, provokes students' meaningful learning, bringing it to life and work.

The evident patterns of transformation, presented in this paper, show that workbased HE practice merges science (subject contents), pedagogy (class-based personalised instruction, work-based smart collaborative activities) and digital technologies (organization of higher education studies in smart work-based e-learning communities) into a holistic smart pedagogical design. It integrates existing and emerging digital educational technologies to meet the demand for flexibility for personalisation of smartmerging generative learning and demonstrates the breadth and depth of transformational changes. Strengthening the collective capacity of higher education organizations in students' self-determined lives and workspaces ensures success in achieving smartmerging learning outcomes-transformational smartness of themselves as collaborative people specifying them in diverse social, cultural, and economic contexts of multidimensional, inclusive ecological environments.

\section{References}

Baumgartner, M., \& Thiem, A. (2015). Identifying Complex Causal Dependencies in Configurational Data with Coincidence Analysis. R J., 7(1), 176.

Bet-David, P. (2018). Are you wise or smart? Nine differences between the two (2015). Retrieved from https://www.patrickbetdavid.com/nine-differences-between-being-wise-and-smart

Birzina, P. R., Kalnina, D., Janevica, J., \& Cernova, E. (2009). Effectiveness of interactive e-learning organization and quality assurance in European interuniversity master studies. Leeds: Education-line. https://www.leeds.ac.uk/educol/documents/186734.pdf

Boffo, V., Fedeli, M., Lo Presti, F., Melacarne, C., Vianello, M. (2017). Teaching and learning for employability. New strategies in higher education. Torino-Milano: Pearson.

Brown, K. G. (Ed.). (2017). The Cambridge handbook of workplace training and employee development. Cambridgeshire: Cambridge University Press.

Buchkremer, H. (1995). Handbuch Sozialpädagogik. Dimensionen sozialer und gesellschaftlicher Entwicklungen durch Erziehung. Darmstadt: Wissenschaftliche Buchgesellschaft.

Chen, B.; Knight, S.; Wise, A.F. (2018). Critical Issues in Designing and Implementing Temporal Analytics, Journal of Learning Analytics, Volume 5(1), 1-9. http://dx.doi.org/10.18608/jla.2018.53.1

Creswell, John W. (2014). Research design: Qualitative, quantitative, and mixed methods of approaches. Thousand Oaks, CA: Sage Publications.

Creswell, John W. (2012). Qualitative inquiry and research design: Choosing among five approaches. Thousand Oaks, CA: Sage Publications.

European Commission. (2017). Preparing Teachers for Diversity: The Role of Initial Teacher Education. Final Report. Luxembourg: Publications Office of the European Union.

European Commission. (2013). Developing the adult learning sector. Lot 3: Opening higher education to adults, pp.93-126. Luxembourg: Publications Office of the European Union.

Ehlert, M. (2020). No Future, No Training? Explaining Cross-national Variation in the Effect of Job Tasks on Training Participation Köln Z Soziol 72, 483-510. doi: https://doi.org/10.1007/s11577-020$\underline{00676-1}$ 
Evans, K. (2019). Learning ecologies at work. Emerging Ideas, Sightings, and Possibilities. In R. Barnett, N. Jackson (Ed.), Ecologies for Learning and Practice, 14. London: Routledge. https://doi.org/10.4324/9781351020268

Freire, P (2007). Pedagogy of the Oppressed. New York: Continuum.

Gil-Garcia, J.R., et al. (2016). Conceptualizing smartness in government: An integrative and multidimensional view, Government Information Quarterly, 33, (3), 524-534. doi: http://dx.doi.org/10.1016/i.giq.2016.03.002

Huber, G.L \& Gürtler, L. (2012). Manual for the AQUAD 7 software (first published in 2003, Tübingen: Ingeborg Huber Verlag). Tübingen: Software sales Günter Huber. Retrieved from: www.aquad.de

Jeladze, E.; Pata, K. \& Quaicoe, J. (2018). Factors determining digital learning ecosystem smartness in schools. Interaction Design and Architecture(s) Journal - IxD\&A, 35, 1-21 [ilmumas].

Karlsone, I. (2018). Design Students' Spatial Reasoning Skill as a Learning Outcome: summary of Doctoral Thesis. Rïga: Latvijas Universitāte.

Luka, I., Ludborza, S., \& Maslo, I. (2009). Effectiveness of the use of more than two languages and quality assurance in European interuniversity master studies. Leeds: Education-line. https://www.leeds.ac.uk/educol/documents/186418.pdf

Lytras, M. D., Daniela, L., \& Visvizi, A. (Eds.). (2018). Enhancing knowledge discovery and innovation in the digital era. Pennsylvania, United States: IGI Global.

Martinez, F., Taut, S., \& Schaaf, K. (2016). Classroom observation for evaluating and improving teaching: An international perspective. Studies in Educational Evaluation, 49, 15-29.

Nargundkar, R. (2008). Marketing Research: Text and Cases. India: MC GRAW HILL INDIA.

OECD. (2013). Education at a Glance: OECD Indicators. Paris: OECD Publishing. doi: http://dx.doi.org/10.1787/eag-2013-en

OECD: (2017). Education at a Glance: OECD Indicators. Paris: OECD Publishing, (2017), doi: http://dx.doi.org/10.1787/eag-2017-en

P21. (2007). The Intellectual and Policy Foundations of the 21st Century Skills Framework. Washington DC, Partnership for 21st Century Skills. Retrieved from

http://www.p21.org/storage/documents/docs/Intellectual and Policy_Foundations.pdf

Benoît, R., Ragin, Ch. C. (Eds.) (2008). Configurational Comparative Methods: Qualitative Comparative Analysis (QCA) and Related Techniques. London: Sage Publications.

Robison, J. E. (2009, November 5). What is smart? Retrieved from https://www.psychologytoday.com/us/blog/my-life-aspergers/200911/what-is-smart

Saldaña, J. (2016). The coding manual for qualitative researchers. London: Sage Publications.

Saunders, M., Lewis, P., Thornhill, A. (2012). Research Methods for Business Students. London: Pearson Education Limited.

Sava, S., Borca, C., \& Clitan, G. (Eds.). (2000). Collective Capacity Building: Shaping Education and Communication in Knowledge Society. International Issues in Adult Education Series, 30. Brill-Sense. https://doi.org/10.1163/9789004422209

School Education Gateway, 2017. Master's Programme 'Educational Treatment of the Diversity' (ETD) [Maǵistra programma Dažādības pedagoǵiskie risinājumi]. Retrieved from

https://www.schooleducationgateway.eu/en/pub/resources/toolkitsforschools/detail.cfm?n=2829, last accessed at 2018/10/08

Scott, C.L. (2015). The futures of learning 3: What kind of pedagogies for the 21st century UNESCO Education Research and Foresight, Paris: ERF Working Papers, 15.

Retrieved from http://unesdoc.unesco.org/images/0024/002431/243126e.pdf

Su Yong (2014). Pedagogy: An Immature Science on the Base of System Science. 2nd World Conference on Design, Arts and Education DAE-2013, Procedia - Social and Behavioural Sciences, 122, 525 - 528, doi: .1016/j.sbspro.2014.01.1387 
Uskov, V. L., Howlett, R., Jain, L. C. (Eds). (2018). Smart Education and Smart e-Learning. Smart Innovation, Systems and Technologies, 99. doi: 10.1007\%2F978-3-319-92363

Uskov V., Howlett R., Jain L.S. (Eds) (2016). Smart Education and eLearning, Series on Smart Innovation, Systems and Technologies, 59. Switzerland: Springer. doi:10.1007/978-3-319-39690-3

Uskov, V. L., Howlett, R., Jain, L. C. (Eds). (2015). Smart Education and Smart e-Learning. Smart Innovation, Systems and Technologies, 41. doi: 10.1007/978-3-319-19875-0

Wernet, A. (2009). Einführung in die Interpretationstechnik der Objektiven Hermeneutik (3. Aufl.). Wiesbaden: VS Verlag für Sozialwissenschaften. 